\title{
Effect of Sowing Date on Two Genotypes of Soybean (Glycine max. Merrill.) Grown under Semi-desert Region
}

\author{
Samia Osman Yagoub*, Mohammed Hamad Adam Hamed \\ Department of Agronomy, College of Agricultural studies, Sudan University of Science and Technology \\ *Corresponding Author: umreelah2003@yahoo.com
}

Copyright (C) 2013 Horizon Research Publishing All rights reserved.

\begin{abstract}
Soybeans (Glycine max Merrill) genotypes $\mathrm{G}_{1}(1904 \mathrm{E})$ and $\mathrm{G}_{2}(1905 \mathrm{E})$ were planted on five sowing dates: $\mathrm{S}_{1}\left(2\right.$ June), $\mathrm{S}_{2}$ (9 June), $\mathrm{S}_{3}\left(16\right.$ June), $\mathrm{S}_{4}(23$ June), and $\mathrm{S}_{5}$ (30 June) for two seasons ( 2009/10-2010/11). The experiments were conducted in split plot design, in semi-desert region in Sudan. In season 2009/10 the result showed that $\mathrm{S}_{4}\left(23\right.$-June) and $\mathrm{S}_{5}$ (30-June) obtained the lowest values of yield components. The results of season 2010/11 showed significant differences for number of pods/plant, number of seeds/pods and highly significant difference was obtained in weight of pods/plant, weight of seeds/plant, 100seed weight, yield and harvest index. The $\mathrm{S}_{3}$ (16-June) mid June, obtained the highest values and $\mathrm{S}_{5}$ (30June) gave the lowest values of the above parameters. There were no significant differences between two genotypes of all parameters of yield and yield components except weight of seeds/plant, yields and harvest index. Genotype $\mathrm{G}_{1}$ (1904 E) showed the highest values. The interaction of different sowing dates and two genotypes of soybean were showed no clear differences. In conclusion, the sowing date in mid June is the best sowing date, and sowing date in late June must be avoided due to reduction in yield and yield components.
\end{abstract}

Keywards Soybean, Sowing Date, Genotypes, Semi-desert

\section{Introduction}

Soybean (Glycine max Merrill) is a legume that grows in tropical, subtropical and temperate climate. Soybean is a crop which can provide complete protein, containing 8 amino acids essential for human Asadi and .Faraji $\{1\}$. That means it can play a major role in elevating nutritional standers of foods in developing countries, where human beings are facing protein deficiencies.

Soybean plants are the most sensitive of all crop plant to light duration (photoperiod) and are sensitive to light quantity. Soybean is short day plants, but cultivars differ markedly with respect to the minimum dark period required to induce flowering Wilcox $\{2\}$. Soybean grows and develops in $30 \mathrm{C}^{\circ}$ the proper temperature for emergence of seedling from seedbed is $25-33 C^{0}$ FAO $\{3\}$. Sowing date for soybean is very hot issues because growing condition at planting time will influence the success of seed germination and seedling vigor.

Planting date is an important management roll to maximize yield potential, later plantings is likely to incur significant reductions in yield FAO $\{3\}$. Delayed planting reduce the number of days to flowering and also reduce the number of days to maturity and decrease the length of regulative and reproductive periods of development Board, et al $\{4\}$. The growth and yield responses of soybean to planting date depend on the environment, variety and production practice. If planted too early, soybean may have poor emergence or limited growth because of hot temperature when soybeans are exposed to day shorter than critical length, they progress rapidly to maturing. If this occurs before the plant reaches an adequate size, the soybean is stunted and give low yield, Boquet, and Clawson $\{5\}$.

Soybean was tried in several parts of Sudan since 1920, it's could be grown as a summer crop under irrigation in central and northern parts of the country or under rain fed conditions in southern state Khidir $\{6\}$. Under Sudan condition sowing date, must learn very carefully because there are no any cultivars released in Sudan, the exotic cultivar are not well known. On the other hand, cultivar adaptability to region influence soybean yield and yield component which can be effected by growth habit and planting date Pedersen and Lauer $\{7\}$. Little research information is available on the responses of soybeans to planting dates under Sudan conditions. The currently recommended planting dates for soybean in Sudan range July, 1 to July, 15 but additional research is needed to confirm this recommendation Khidir $\{6\}$. The objective of this study was to examine the effect of different sowing dates on yield, and yield components of two genotypes of soybean (Glycine max Merrill) under semi- desert region of Sudan.

\section{Material and Methods}


The experiment was conducted in two seasons $(2009 / 10$ 2010/11) at Demonstration Farm of Collage of Agricultural Studies, Sudan University of Science and Technology at Shambat. Shambat is Located $23^{\circ} 35$, longitude $15^{\circ} 31^{\prime}$, and altitude $288 \mathrm{~m}$ sea level, within the semi-desert region Adam $\{8\}$ the soil of the site is described by Abdel-Hafeez $\{9\}$ as loam clay it is characterized by a deep cracking, moderately alkaline clays, and low permeability, low nitrogen content and $\mathrm{PH}(7.5-8)$ content (50-60\%) and high exchangeable sodium percentage (ESP), in subsoil.

The treatments consists of two genotypes of soybean G1 (1904E) and G2 (1905E) both with indeterminate growth habit. The seeds were obtained from ARC and propagated in Sudan University of Science and Technology. The two genotypes sowing every weeks start from June, 2 for five weeks for two seasons 2009-2010, $\mathrm{S}_{1}$ (2 June), $\mathrm{S}_{2}$ (9 June), $\mathrm{S}_{3}$ (16 June), $\mathrm{S}_{4}\left(23\right.$ June), and $\mathrm{S}_{5}$ (30 June).The experimental design was randomize splits block design. Sowing date was the main plot and genotype was sub plot, with four replications. The land was prepared by disc plough, disc harrowed and leveled ridging up North - South, the spaces between rides $70 \mathrm{~cm}$, holes $25 \mathrm{~cm}$, the size of the plot was $3 * 3 \mathrm{~m}^{2}$ consisting of four ridges of 2.5 length . Nitrogen fertilizer (urea $46 \% \mathrm{~N}$ ) after three weeks of planting, were irrigated immediately after sowing and then sub sequent irrigated every seven days .The first hand weeding was frequently done to get rid weeds including Nageala (Cynodon dactyton), saeda (Cyperus rotund us) and second hand weeding after two weeks of the first one.

Growth parameters measured from appoint immediately above the soil surface to the top of the plant reading every 15 days recorded four reading. Taken plant height and counted the number of leaves per plant. Days from sowing until 50\% $-100 \%$ of plants in each plot flowered were determined. Dry weight of five plants from each plot and their means was taken. Harvested five plants from plot to measure plant height for each plant and then obtaining means number of dry weight/plant for each treatment. Number of pods, number of seeds per plant, weight of seeds per plant and 100 seed weight of five plants of each plot were counted and then obtaining it is means. Taken meter length from the middle ridges of the each plot and then yield weighted transformed to $\mathrm{kg} \backslash$ ha. Harvest index was taken according to the following equation:

Harvest index $=\underline{\text { seed weight } \mathrm{kg} / \mathrm{ha}}$

Shoot dry weight $\mathrm{kg} / \mathrm{ha}$
Analysis of variance was carried out using the procedure of MSTAC and the LSD used for mean comparisons.

\section{Results and Discussion}

Planting date is an important factor influencing soybean growth and yield. In this experiment the effect of sowing date on yield and yield components of two seasons (2009/10-2010/11) was presented in tables (1-2). The results in the season one (Table 1) showed significant difference at $(\mathrm{P}=0.05)$ in weight of pods/plant, number of seeds/plant, shoot dry weight and yield $(\mathrm{kg} / \mathrm{ha})$. In general $\mathrm{S}_{1}$ (2-June) and $\mathrm{S}_{2}$ (9-June) gave the highest values of the above parameters. In contrast $\mathrm{S}_{4}\left(23\right.$-June) and $\mathrm{S}_{5}$ (30-June) obtained the lowest values.

The results of season 2010/11 were presented in Table 2. There were significant differences for number of pods/plant, number of seeds/pods and highly significant difference was obtained in weight of pods/plant, weight of seeds/plant, 100seed weight, yield and harvest index. The $\mathrm{S}_{3}$ (16-June ) mid June, obtained the highest values on number of pos/plants( 80.7), weight of pods/plant (17.3) number of seeds/plant (175.9), shoot dry weight(47.4),100seed weight (1.8) and yield (788.9 kg/ha). On the other hand late June $\mathrm{S}_{5}$ (30) gave the lowest values of all the above parameters. That means, the sowing date in mid June is the best sowing date, and sowing date in late June must be avoided due to reduction in yield and yield components. It clear that length of photoperiod strongly influences the morphology of soybean plant by causing change in the time of flowering, maturity and dry matter production. This leaned heavily on yield and yield components of soybean. This was agreed with Woong Yamakawa $\{10\}$ who reported that the number of pods and seed per plant decreased as planting date delayed. Pedersen and Lauer $\{7\}$ concluded that planting date did not have an effect on plant height at harvest, on the other hand Bastidas et al., $\{11\}$ found that yield was significantly affected by planting date. This result also, was in line with Calvin and Brent $\{12\}$, Zhang, et al., $\{13\}$, Moosavi,et al., $\{14\} \mid$ and Ibrahim $\{15\}$. Ibrahim $\{15\}$ who illustrated the importance of early sowing for maximizing the yield potential of irrigated soybean in central Sudan. Also Zhang, et al., $\{13\}$, proved that the optimum sowing date for irrigated soybean in central Sudan is mid June. 
Table 1. Yield and yield characteristic of soybean as affected by different sowing date during season 2009/10

\begin{tabular}{|c|c|c|c|c|c|c|c|c|c|}
\hline & $\begin{array}{c}\text { No of } \\
\text { pods/plants }\end{array}$ & $\begin{array}{l}\text { Weight of } \\
\text { pods/plant }\end{array}$ & $\begin{array}{c}\text { No. of } \\
\text { seeds/pods }\end{array}$ & $\begin{array}{c}\text { Weight of } \\
\text { seeds/plant }\end{array}$ & $\begin{array}{c}\text { No of } \\
\text { seeds/plant }\end{array}$ & $\begin{array}{l}\text { Shoot dry } \\
\text { weight }(\mathrm{g})\end{array}$ & $\begin{array}{c}100 \text { seed } \\
\text { weight }\end{array}$ & Yield (kg/ha) & $\begin{array}{c}\text { Harvest } \\
\text { index }\end{array}$ \\
\hline $\mathrm{S}_{1}$ (2-June) & 86.4 & 63.5 & 1.9 & 14.9 & 170.2 & 121.5 & 2.2 & 919.5 & 407.1 \\
\hline $\mathrm{S}_{2}(9-J u n e)$ & 133.7 & 28.1 & 1.3 & 14.9 & 176.4 & 34.8 & 2.0 & 954.2 & 395.7 \\
\hline $\mathrm{S}_{3}$ (16-June) & 106.9 & 26.5 & 1.5 & 12.1 & 163.3 & 37.1 & 2.0 & 759.5 & 320.7 \\
\hline $\mathrm{S}_{4}$ (23-June) & 48.8 & 30.3 & 1.5 & 10.3 & 70.0 & 36.6 & 2.1 & 302.1 & 306.6 \\
\hline $\mathrm{S}_{5}$ (30-June) & 41.2 & 33.5 & 2.0 & 12.2 & 80.6 & 40.1 & 2.1 & 646.1 & 452.3 \\
\hline $\mathrm{CV} \%$ & $40 \%$ & $36.2 \%$ & $24.4 \%$ & $42.5 \%$ & $49.3 \%$ & $23.8 \%$ & $9.6 \%$ & $43.2 \%$ & $30.3 \%$ \\
\hline LSD S & $85.7^{\mathrm{NS}}$ & $40.4^{*}$ & $0.6^{*}$ & $12.8^{\mathrm{NS}}$ & $114.2 *$ & $131.9^{*}$ & $1.6^{\mathrm{NS}}$ & $706.9^{*}$ & $205.5^{\mathrm{NS}}$ \\
\hline
\end{tabular}

Table 2. Yield and yield characteristic of two soybean as affected by different sowing date during season 2010/11( data of sowing date)

\begin{tabular}{|c|c|c|c|c|c|c|c|c|c|}
\hline & $\begin{array}{c}\text { No of } \\
\text { Pods/plants }\end{array}$ & $\begin{array}{l}\text { Weight of } \\
\text { pods/plant }\end{array}$ & $\begin{array}{c}\text { No. of } \\
\text { seeds/pods }\end{array}$ & $\begin{array}{c}\text { Weight of } \\
\text { seeds/plant }\end{array}$ & $\begin{array}{c}\text { No of } \\
\text { seeds/plant }\end{array}$ & $\begin{array}{l}\text { Shoot dry } \\
\text { weight }(\mathrm{g})\end{array}$ & $\begin{array}{c}100 \text { seed } \\
\text { weight }\end{array}$ & Yield (kg/ha) & $\begin{array}{c}\text { Harvest } \\
\text { index }\end{array}$ \\
\hline $\mathrm{S}_{1}$ (2-June) & 71.5 & 60.6 & 3.6 & 14.8 & 144.3 & 37.5 & 1.8 & 628.6 & 94.1 \\
\hline $\mathrm{S}_{2}(9-J u n e)$ & 77.9 & 81.6 & 3.9 & 16.3 & 151.1 & 41.6 & 1.8 & 724.9 & 43.1 \\
\hline $\mathrm{S}_{3}$ (16-June) & 80.7 & 85.4 & 3.2 & 17.3 & 175.9 & 47.4 & 1.9 & 788.9 & 53.9 \\
\hline $\mathrm{S}_{4}$ (23-June) & 70.2 & 84.0 & 3.1 & 16.9 & 161.9 & 38.9 & 1.6 & 744.5 & 69.7 \\
\hline $\mathrm{S}_{5}$ (30-June) & 64.7 & 33.6 & 3.5 & 5.6 & 151.5 & 36.8 & 1.6 & 281.3 & 32.5 \\
\hline CV\% & $36.9 \%$ & 17.1 & $15.9 \%$ & $23.4 \%$ & $29.4 \%$ & $36.9 \%$ & $3.1 \%$ & 33.4 & 19.1 \\
\hline LSD S & $9.3^{*}$ & $3.8^{* *}$ & $0.19^{*}$ & $3.6^{* *}$ & $9.4^{* *}$ & $7.9^{\mathrm{NS}}$ & $0.16^{* *}$ & $44.4^{* *}$ & $6.7^{* *}$ \\
\hline
\end{tabular}

Table 3. Yield and yield characteristic of two soybean as affected by different sowing date during season 2009/10(data of two genotypes)

\begin{tabular}{|c|c|c|c|c|c|c|c|c|c|}
\hline & $\begin{array}{c}\text { No of } \\
\text { Pods/plants }\end{array}$ & $\begin{array}{l}\text { Weight of } \\
\text { pods/plant }\end{array}$ & $\begin{array}{c}\text { No. of } \\
\text { seeds/pods }\end{array}$ & $\begin{array}{l}\text { Weight of } \\
\text { seeds/plant }\end{array}$ & $\begin{array}{c}\text { No of } \\
\text { seeds/plant }\end{array}$ & $\begin{array}{l}\text { Shoot dry } \\
\text { weight }(g)\end{array}$ & $\begin{array}{c}100 \text { seed } \\
\text { weight }\end{array}$ & Yield (kg/ha) & $\begin{array}{c}\text { Harvest } \\
\text { index }\end{array}$ \\
\hline $\mathrm{G}_{1}(1904 \mathrm{E})$ & 80.5 & 34.6 & 1.7 & 12.2 & 131.2 & 53.0 & 2.1 & 702.2 & 357.9 \\
\hline $\mathrm{G}_{2}(1905 \mathrm{E})$ & 36.3 & 38.0 & 1.6 & 13.6 & 133.1 & 55.1 & 2.2 & 730.0 & 395.0 \\
\hline LSD G & $52.2^{\mathrm{NS}}$ & $20.3^{\mathrm{NS}}$ & $0.6^{\mathrm{NS}}$ & $8.4^{\mathrm{NS}}$ & $135.7^{\mathrm{NS}}$ & $86.8^{\mathrm{NS}}$ & $1.6^{\mathrm{NS}}$ & $606.9^{\mathrm{NS}}$ & $175.8^{\mathrm{NS}}$ \\
\hline
\end{tabular}

Table 4. Yield and yield characteristic of two soybean as affected by different sowing date during season 2010/11 (data of two genotypes)

\begin{tabular}{ccccccccc}
\hline & $\begin{array}{c}\text { No of } \\
\text { Pods/plants }\end{array}$ & $\begin{array}{c}\text { Weight of } \\
\text { pods/plant }\end{array}$ & $\begin{array}{c}\text { No. of } \\
\text { seeds/pods }\end{array}$ & $\begin{array}{c}\text { Weight of } \\
\text { seeds/plant }\end{array}$ & $\begin{array}{c}\text { No of } \\
\text { seeds/plant }\end{array}$ & $\begin{array}{c}\text { Shoot dry } \\
\text { weight(g) }\end{array}$ & $\begin{array}{c}\text { 100 seed } \\
\text { weight }\end{array}$ & $\begin{array}{c}\text { Yield (kg/ha) } \\
\text { Index }\end{array}$ \\
\hline $\mathrm{G}_{1}$ (1904 E) & 74.9 & 17.1 & 3.4 & 15.2 & 158.9 & 40.7 & 1.63 & 672.9 \\
$\mathrm{G}_{2}$ (1905 E) & 71.1 & 17.3 & 3.5 & 13.0 & 155.1 & 40.3 & 1.62 & 594.4 \\
LSD G & $6.4^{\mathrm{NS}}$ & $2.2^{\mathrm{NS}}$ & $0.63^{\mathrm{NS}}$ & $1.6^{*}$ & $6.7^{\mathrm{NS}}$ & $4.3^{\mathrm{NS}}$ & $0.08^{\mathrm{NS}}$ & $17.7^{* *}$ \\
\hline
\end{tabular}


The results on yield and yield components of two genotypes of this experiment of two seasons were presented in Table 3-4. There were no significant differences between two cultivars of two seasons of all parameters except weight of seeds/plant, yields and harvest index in season two. Genotype $G_{1}$ (1904 E) showed the highest values of these three parameters, high significant differences in weight of seeds/plant and highly significant differences for yield and harvest index. Moosavi,et al., $\{14\}$ studied the cultivar effect and cultivar interaction with sowing date with yield and yield components and showed there was no meaningful effect. Khan et al., $\{16\}$ reported that, cultivars gave maximum biological and seed yields in early planting than delay planting. It can be concluded that the two soybean cultivars can be planted during early to mid June to avoid drastic reduction in yields under this conditions

The interaction of different sowing dates and two genotypes of soybean were showed in Table 5-6. There were no significant differences on first season, but $\mathrm{G}_{1}(1904 \mathrm{E})$ with $\mathrm{S}_{2}$ (9-June) gave the highest yield among all treatments $(1066.9 \mathrm{~kg} / \mathrm{ha})$. In season two number of seeds/pod obtained significant differences at $\mathrm{G}_{1} \mathrm{~S}_{1}$, and highly significant differences were obtained in weight of seeds/plant, yield $(\mathrm{kg} / \mathrm{ha})$ and harvest index $\mathrm{G}_{1} \mathrm{~S}_{4}$ and $\mathrm{G}_{1} \mathrm{~S}_{1}$ gave the highest yield values $(831.0 \mathrm{~kg} / \mathrm{ha}$ and $816.0 \mathrm{~kg} / \mathrm{ha}$, from the result it was clear that late sowing dates $\mathrm{S}_{5}$ (30 June) obtained drastic reduction in yield for both cultivars (158.5 and 404.1 $\mathrm{kg} / \mathrm{ha}$ for $\mathrm{G}_{1}$ and $\mathrm{G}_{2}$ respectively). Weight of seeds/ plant and harvest index results was in line with results of yield. The results of interaction of different sowing dates and cultivars discussed above was the same as Ball et al., $\{17\}$, Moosavi,et al., $\{14\}$ and Ibrahim $\{15\}$ results. Khan et al., $\{16\}$ who reported that delaying sowing date gave smaller seed compared with all traits. Also Boquet $\{18\}$ obtained maximum seed yield with early planting in June as compared with late planting in July. On the other hand, Bastidas et al., $\{11\}$ expressed that delaying planting after I May led to significant linear declines of $17 \mathrm{~kg} / \mathrm{ha}$ in 2003 and $43 \mathrm{~kg} / \mathrm{ha}$ in 2004, denoting the importance of early planting for capturing the yield potential available in soybean plant production when moisture supply is not limiting. Late sowing dates (30-June) may lead to a lack of sufficient vegetative growth, low number of pods/plant and reduced seed weight and ultimately lower grain yields. 
Table 5. Yield and yield characteristic of two soybean as affected by different sowing date during season 2009/10 (data of interaction of sowing date and two genotypes)

\begin{tabular}{|c|c|c|c|c|c|c|c|c|c|c|}
\hline Genotype & Sowing date & $\begin{array}{c}\text { No of } \\
\text { pods/plants }\end{array}$ & $\begin{array}{l}\text { Weight of } \\
\text { pods/plant }\end{array}$ & $\begin{array}{c}\text { No. of } \\
\text { seeds/pods }\end{array}$ & $\begin{array}{l}\text { Weight of } \\
\text { seeds/plant }\end{array}$ & $\begin{array}{c}\text { No of } \\
\text { seeds/plant }\end{array}$ & $\begin{array}{l}\text { Shoot dry } \\
\text { weight(g) }\end{array}$ & 100 seed weight & Yield (kg/ha) & $\begin{array}{l}\text { Harvest } \\
\text { index }\end{array}$ \\
\hline \multirow{6}{*}{$\mathrm{G}_{1}(1904 \mathrm{E})$} & $\mathrm{S}_{1}$ (2-June) & 84.5 & 60.9 & 1.9 & 13.1 & 166.9 & 120.5 & 2.1 & 889.6 & 387.0 \\
\hline & $\mathrm{S}_{2}$ (9-June) & 124.6 & 28.1 & 1.4 & 16.7 & 186.3 & 36.1 & 2.0 & 1066.9 & 451.5 \\
\hline & $\mathrm{S}_{3}$ (16-June) & 122.5 & 32.2 & 1.4 & 13.8 & 175.8 & 43.9 & 2.0 & 834.7 & 304.1 \\
\hline & $\mathrm{S}_{4}$ (23-June) & 33.3 & 21.4 & 1.6 & 7.6 & 55.0 & 27.7 & 2.1 & 276.8 & 282.2 \\
\hline & $\mathrm{S}_{5}$ (30-June) & 38.5 & 30.5 & 2.0 & 9.9 & 72.3 & 36.5 & 2.0 & 443.0 & 365.0 \\
\hline & $\mathrm{S}_{1}$ (2-June) & 88.3 & 65.3 & 1.9 & 16.7 & 173.8 & 122.6 & 2.0 & 949.4 & 427.1 \\
\hline \multirow{4}{*}{ G2(1905 E) } & $\mathrm{S}_{2}$ (9-June) & 142.9 & 27.9 & 1.2 & 13.2 & 166.5 & 33.5 & 2.0 & 841.5 & 339.4 \\
\hline & $\mathrm{S}_{3}$ (16-June) & 91.3 & 20.9 & 1.7 & 10.4 & 150.8 & 30.3 & 2.0 & 684.3 & 337.3 \\
\hline & $\mathrm{S}_{4}(23$-June $)$ & 64.3 & 39.2 & 1.4 & 12.4 & 85.3 & 45.4 & 2.2 & 327.5 & 331.0 \\
\hline & $\mathrm{S}_{5}(30-$ June $)$ & 43.0 & 36.6 & 2.0 & 14.5 & 89.0 & 43.8 & 2.2 & 849.3 & 539.0 \\
\hline LSD SxG & & $49.6^{\mathrm{NS}}$ & $22.5^{\mathrm{NS}}$ & $0.4^{\mathrm{NS}}$ & $9.4^{\mathrm{NS}}$ & $50.4^{\mathrm{NS}}$ & $117.5^{\mathrm{NS}}$ & $0.9^{\mathrm{NS}}$ & $427.7^{\mathrm{NS}}$ & $216.2^{\mathrm{NS}}$ \\
\hline
\end{tabular}

Table 6 Yield and yield characteristic of two soybean as affected by different sowing date during season 2010/11( data of interaction of sowing date and two genotypes)

\begin{tabular}{|c|c|c|c|c|c|c|c|c|c|c|}
\hline Genotype & Sowing date & $\begin{array}{c}\text { No of } \\
\text { pods/plants }\end{array}$ & $\begin{array}{l}\text { Weight of } \\
\text { pods/plant }\end{array}$ & $\begin{array}{c}\text { No. of } \\
\text { seeds/pod }\end{array}$ & $\begin{array}{l}\text { Weight of } \\
\text { seeds/plant }\end{array}$ & $\begin{array}{c}\text { No of } \\
\text { seeds/plant }\end{array}$ & $\begin{array}{l}\text { Shoot dry } \\
\text { weight }(\mathrm{g})\end{array}$ & 100 seed weight & Yield (kg/ha) & $\begin{array}{c}\text { Harvest } \\
\text { index }\end{array}$ \\
\hline \multirow{7}{*}{$\mathrm{G}_{1}(1904 \mathrm{E})$} & $\mathrm{S}_{1}$ (2-June) & 74.5 & 11.9 & 3.59 & 20.9 & 137.5 & 38.2 & 1.49 & 816.6 & 153.7 \\
\hline & $\mathrm{S}_{2}$ (9-June) & 76.6 & 21.2 & 4.32 & 16.2 & 156.2 & 41.4 & 1.79 & 782.2 & 47.1 \\
\hline & $\mathrm{S}_{3}$ (16-June) & 81.8 & 20.5 & 3.05 & 17.5 & 180.1 & 48.1 & 1.83 & 775.9 & 54.5 \\
\hline & $\mathrm{S}_{4}$ (23-June) & 76.3 & 23.2 & 2.92 & 18.8 & 167.1 & 40.8 & 1.56 & 831.6 & 87.2 \\
\hline & $\mathrm{S}_{5}$ (30-June) & 64.9 & 8.5 & 3.30 & 2.7 & 153.5 & 34.7 & 1.49 & 158.6 & 23.2 \\
\hline & $\mathrm{S}_{1}$ (2-June) & 68.4 & 18.3 & 3.66 & 8.5 & 151.1 & 36.9 & 1.49 & 441.2 & 34.5 \\
\hline & $\mathrm{S}_{2}$ (9-June) & 78.9 & 19.7 & 3.62 & 16.3 & 145.9 & 41.7 & 1.72 & 667.5 & 39.2 \\
\hline \multirow{3}{*}{ G2(1905 E) } & $\mathrm{S}_{3}(16$-June) & 79.6 & 21.0 & 3.25 & 17.1 & 171.9 & 46.7 & 1.71 & 801.8 & 53.2 \\
\hline & $\mathrm{S}_{4}$ (23-June) & 64.1 & 19.5 & 3.25 & 14.8 & 156.8 & 37.1 & 1.58 & 657.3 & 51.7 \\
\hline & $\mathrm{S}_{5}$ (30-June) & 64.4 & 8.3 & 3.62 & 8.4 & 149.5 & 38.9 & 1.62 & 404.1 & 42.0 \\
\hline LSD SxG & & $6.4^{\mathrm{NS}}$ & $28.0^{\mathrm{NS}}$ & $0.63 *$ & $15.7^{* *}$ & $144.0^{\mathrm{NS}}$ & $14.0^{\mathrm{NS}}$ & $1.23^{\mathrm{NS}}$ & $154.4^{* *}$ & $27.7^{* *}$ \\
\hline
\end{tabular}




\section{Acknowledgments}

The authors would like to express they sincere appreciation and thanks for Sudan University of Science and Technology for financial support of this research

\section{REFERENCES}

[1] Asadi I and .Faraji I. (2009). Principles of applied agriculture oilseeds. Iran Agricultural Science publishing, p93.

[2] Wilcox, J.R. (1987). Soybeans: Improvement, Production and Uses, 2nd ed. American Society of Agronomy, 667.

[3] FAO, Statistic division. 2007: Sudan.

[4] Board, J.E., Kamal, M., Harville, B.G., (1992). Temporal importance of greater light interception to increased yield in narrow-row soybean. Agro. J. 84: 575-579.

[5] Boquet, D.J., and Clawson, E.L.,(2007). Planting dates for soybean varieties in North Louisiana. Louisiana Agriculture Magazine .LSUA, center.com

[6] Khidir,M. O.(1997). Oil Crops in the Sudan, Khartoum University, Press, Khartoum, Sudan, 1997.

[7] Pedersen, P., and J.G. Lauer. 2004. Soybean growth and development response to rotation sequence and tillage system. Agron. J. 96:1005-1012.

[8] Adam, H. S.,(2002). The Agricultural Climate, Gezira University Press, Wad-Medani, Sudan, 2nd edition, 2002.

[9] Abdel-Hafeez , (2001).M. E., Effect of partially acidulate phosphate rocks and triple superphosphate and their combinations on growth, mineral composition and yield of wheat, Ph.D. thesis, College of Agricultural Studies, University of Sudan for Science and Technology, Khartoum,
Sudan.

[10] Woong C.J and Takeo Yamakawa (2006). Laboratory of Plant Nutrition ,Division of Soil Science and Plant Production ,Kyushu University,6-10-1 Hakozaki ,Fukuoka 812-8581, Japan

[11] Bastidas, A.M.,T.D.Setiyono, A. Dobermann, K.G.Cassman, R.W.Elmore, G.L.Graef and J.E.Specht(2008). Soybean sowing date: the vegetative, reproductive and agronomic impacts. Crop Science, (48): 727-740

[12] Calvin T. and Brent B (2001). Effect of planting date and maturity group on soybean yield. Texas South Extension Agron. J., 806:35

[13] Zhang, Qiu-ying, Qing-lu Gao, S. J. Herbert, Yan-sheng Li and A. M. Hashemi(2010). Influence of sowing date on phonological stages, seed growth and marketable yield of four vegetable soybean cultivars in North-eastern USA. African Journal of Agricultural Research Vol. 5(18), pp. $2556-2562$

[14] Moosavi, S.S., Seyed M.J.M., Ali, A.I.,Ali, M.K and Babak S.M., (2011). Study of effect of planting date on vegetative traits, reproductive traits and grain yield of soybean cultivars in cold region of Ardabil (Iran). African Journal of Agricultural research vol 6(21): 4879-4883.

[15] Ibrahim S.E. (2012). Agronomic studies on irrigated soybeans in central Sudan: II. Effect of sowing date on grain yield and yield components. International Journal of AgriScience vol. (9): 766-773.

[16] Khan A.Z. Shah P, Khalil S. K. and Ahmed B., (2004). Yield of soybean cultivars as affected by planting date under Peshawar valley Conditions. The Nucleus 41:93-95.

[17] Ball R.A., Purcell L.C. and Vories ED (2000) short -season soybean yield compensation in response to population and water regime. Crop Sci.40:1070-1078.

[18] Boquet D.J.(1990). Plant population and row spacing effects on soybean at post optimal dates. Agron J 82:59-64. 